\title{
Study of renal and hepatic toxicity in rats supplemented with creatine ${ }^{1}$
}

\author{
Nilo Cesar do Vale BarachoI, Letícia Pereira de Castro"I, Niara da Cunha Borges ${ }^{\text {II }}$, Patrícia Benício Laira ${ }^{\mathrm{II}}$
}

DOI: http://dx.doi.org/10.1590/S0102-865020150050000002

IPhD, Full Professor, Pharmacology and Biochemistry, Medical School of Itajuba (FMIt), Brazil. Conception, design, scientific and intellectual content of the study; acquisition and interpretation of data; critical revision; final approval.

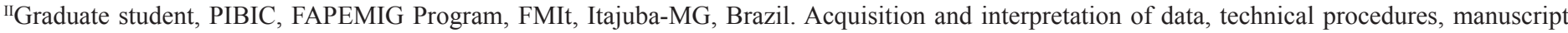
preparation.

\section{ABSTRACT}

PURPOSE: To evaluate the renal and hepatic function, through biochemical analysis after 14 days of creatine supplementation in physically inactive rats.

METHODS: Twenty four male, adult, Wistar rats were used which were kept in individual metabolic cages and were distributed into four groups, and received the following treatments by gavage:1) Control: distilled water; 2)Creatine 0.5g/Kg/day; 3) Creatine 1g/Kg/ day; 4) Creatine $2 \mathrm{~g} / \mathrm{Kg} /$ day. Their urinary outputs as well as food and water intake were daily measured. At the end of the experiment, the animals were euthanized and serum samples were stored for biochemical analysis.

RESULTS: Creatine supplementation at the doses given produced no significant changes in plasma levels of aspartate aminotransferase, alanine aminotransferase, alkaline phosphatase, total protein, albumin, total cholesterol, HDL cholesterol, LDL cholesterol, VLDL cholesterol, triglycerides, glucose, creatinine, urea, and creatinine clearance, compared to control group (p>0.05) Similarly, water and food intake, as well as urinary output, did not show significant changes among the four groups studied.

CONCLUSION: At the doses used, oral creatine supplementation did not result in renal and/or hepatic toxicity.

Key words: Creatine. Toxicity. Kidney. Liver. Rats. 


\section{Introduction}

At the beginning of the age of sports, the advantage gained by outstanding athletes was considered as an insurmountable barrier. Nowadays, there are different methods to improve performance, by complementing the training effect. Such methods, also known as ergogenic aids, may be classified into several categories, and nutritional supplementation figures as one of them ${ }^{1-3}$.

Recently published researches suggest that the use of these supplements can reach $46 \%$ of competitive athletes. ${ }^{4}$ Earlier there were compounds such as bee pollen, royal jelly, choline, followed by carbohydrates, and currently, creatine ${ }^{1,4-6}$. According to surveys, it is estimated that $80 \%$ of the athletes participating in 1996 Atlanta Olympic Games made use of creatine for ergogenic purposes $^{7}$. The rationale for such use has been the evidence that the availability of this compound is a major limitation to muscle performance during short-duration and high intensity activities, since its depletion results in the inability to resynthesize enough quantity of adenosine triphosphate (ATP) ${ }^{8-10}$.

Creatine is a nitrogenous amine referred to as methylguanidine acetic acid and its importance for the body was first demonstrated by Hunter ${ }^{7}$ At the same time, Heitz and Pettenkoffer ${ }^{11}$ discovered a new substance present in urine, identified by Liebig as creatinine, a by-product of creatine. Creatine synthesis is performed in the liver, kidneys, and pancreas, with three different amino acids as precursors: arginine, glycine and methionine ${ }^{12}$.The storage occurs mainly in skeletal muscle, corresponding to $95 \%$, where it can remain as free $(40 \%)$ or phosphorylated creatine $(60 \%)$; moreover, it is also found in the brain, liver, kidneys, and testicles, which corresponds to $5 \%$ of the tota ${ }^{13,14}$. In addition to creatine synthesis in the body (endogenous creatine), food supplies about 1 gram of creatine/day, mainly through the consumption of animal products, such as beef and fish ${ }^{15,16}$. The average daily requirement is 2 grams/day: 1 gram from diet and 1 gram from endogenous production ${ }^{17-19}$.

Creatine's mechanism of action is based on effects that trigger improvement in muscle energy metabolism, in which phosphorylated creatine has the ability to re-synthesize ATP, from adenosine diphosphate, thus increasing their deposits by 6-8 times $^{19-21}$. Another beneficial effect of creatine supplementation is to increase the size of muscle fibers, as well as lean body mass, since there is increased protein synthesis and decreased catabolism. Finally, creatine prevents tissue damage, as it develops mechanisms of cellular membrane stabilization and ATP maintenance ${ }^{14,22,23}$.

The reduction of creatine tissue levels has been associated with a number of diseases, and that is the reason why the effects of supplementation have been studied ${ }^{24,25}$. As an example to evidence such conduct, research papers on its antioxidant potential have been developed; the higher the availability of ATP obtained from phosphocreatine, the lower is the production of hypoxanthine when associated with parallel reduction of its catabolism in xanthine and urate, thus resulting in lower production of reactive oxygen species in the muscle fiber ${ }^{26-28}$.

In this context, it is observed that physiological levels of creatine have beneficial effects on the body ${ }^{8,29}$. However, due to its intense use as a nutritional supplement, it is necessary to conduct a careful evaluation on the possible toxicity to metabolism and liver morphology, as well as to renal function, as a result from such supplementation, since its toxicological effects are still controversial in scientific literature ${ }^{30}$. Studies have shown that creatine supplementation did not cause damage to kidney and liver function in $\operatorname{rats}^{31,32}$. However, some experimental and clinical studies have associated its supplementation to some side effects, such as the appearance of hepatitis, harmful effects on glomerular filtration rate and on renal plasma flow ${ }^{33,34}$.

Considering these differences regarding the toxicological effect of creatine supplementation on liver and kidney metabolism, across the studies performed, it is necessary to develop new researches in order to investigate the renal and hepatic effects of this supplementation.

\section{Methods}

The study was conducted in the Vivarium animal experimentation room and in the Biochemistry Laboratory at the Medical School of Itajuba (FMIt), complying with Federal Law 11.794 and with Brazilian College of Animal Experimentation (COBEA) guidelines and it was carried out only after approval of the project by the Research Ethics Committee (REC) of the Medical School of Itajuba (FMIt), under protocol number 04/11.

Were used twenty four male, adult Wistar rats. The animals weighed between 200 and 250g, aged between 60 and 90 days old, all of them from the vivarium of the Medical School of Itajuba - FMIt.

\section{Treatment and dosages}

The animals were kept in individual metabolic cages with a controlled 12-hour light-dark cycle during the 14 days of the experiment and they were given ad libitum access to water and food ${ }^{32}$. It was an air-conditioned room, with a controlled temperature of $22+1^{\circ} \mathrm{C}$, with little noise and relative humidity of the air within the limits standardized by the Vivarium. 
The animals were randomly divided into four groups of six rats each $(n=6)^{32,34}$. The rats received the treatments described below, at one single oral dose per day (gavage), in the afternoon, for fourteen days:

- Group 01 (Control - $\mathrm{n}=6$ ) - distilled water - Orally (gavage);

- Group $02(n=6)$ - micronized creatine diluted with water $(15 \mathrm{ml})-0.5 \mathrm{~g} / \mathrm{kg} /$ day - Orally (gavage) $)^{32}$;

- Group $03(\mathrm{n}=6)$ - micronized creatine diluted with water $(15 \mathrm{ml})-1 \mathrm{~g} / \mathrm{kg} /$ day - Orally (gavage);

- Group $04(\mathrm{n}=6)$ - micronized creatine diluted with water $(15 \mathrm{ml})$ - $2 \mathrm{~g} / \mathrm{kg} /$ day - Orally (gavage).

It is important to emphasize that the supplement used was micronized creatine HPLC, Probiótica, Sao Paulo, Brazil ${ }^{32}$.

Animals had their urine measured every day during the experimental period. Graduated cylinders were used in order to measure 24-hour urine volume. Then, urine samples were collected on experiment day 14 and spun in a clinical centrifuge (Excelsa, Fanen) at $2000 \mathrm{rpm}$ for five minutes and the supernatant obtained was stored in capped test tubes inside the freezer $\left(-4^{\circ} \mathrm{C}\right)$ for laboratory tests.

It is noteworthy that animals' water and food intake was measured every day during the experimental period. Graduated cylinders were used to measure fluid intake and a balance was used to weigh the food.

At the end of the experiment, complying with a 12-hour fasting period, the animals were anesthetized with Ketamine (50 $\mathrm{mg} / \mathrm{kg}$ ) / Xylazine (25 mg/kg), intramuscularly (IM), and they underwent intracardiac aspiration puncture for euthanasia and sampling. The blood sample was spun in a clinical centrifuge
(Excelsa, Fanen) at $2000 \mathrm{rpm}$ for 10 minutes and the serum obtained ( $\pm 2 \mathrm{ml} /$ rat) was stored in closed test tubes inside a freezer $\left(-4^{\circ} \mathrm{C}\right)$ for laboratory analysis.

The stored serum samples were used to determine the following biochemical parameters, with the use of a spectrophotometer (Quimis Q-108DRD): aspartate aminotransferase (AST), alanine aminotransferase (ALT), alkaline phosphatase (ALP), total protein, albumin, total cholesterol, HDL cholesterol, LDL cholesterol, VLDL cholesterol, triglycerides, fasting glucose, creatinine, urea, and creatinine clearance. Labtest kits were used to determine concentrations.

After the procedure of euthanasia, the animals were placed inside red plastic bags and delivered to the company responsible for the collection of potentially contaminated materials and waste, contracted by the City Hall of Itajuba.

BioEstat software, version 5.0, was used for statistical analysis. Student's $t$ test was used between two independent populations to compare the groups at each timepoint, with the calculation of $p$-statistics. Data obtained also underwent ANOVA test to check discrepancies between the four groups. In cases where $p$ was lesser than 0.05 , the statistics was considered significant.

\section{Results}

Creatine supplementation at doses of $0.5 \mathrm{~g} / \mathrm{kg} / \mathrm{day}$; $1 \mathrm{~g} / \mathrm{kg} /$ day and $2 \mathrm{~g} / \mathrm{kg} /$ day produced no significant changes in laboratory measurements of glucose, creatinine, total cholesterol, triglycerides, HDL-C, LDL-C, VLDL-C, AST, ALT, alkaline phosphatase, total protein, albumin, urea, and creatinine clearance, compared to the control group, $\mathrm{p}>0.05$. (Table 1 ).

TABLE 1 - Plasma levels of the parameters assessed for Control group and Creatine groups. Results are expressed as average and standard deviation.

\begin{tabular}{|c|c|c|c|c|}
\hline PARAMETERS & CONTROL & CREATINE $0.5 \mathrm{~g} / \mathrm{kg} / \mathrm{day}$ & CREATINE $1 \mathrm{~g} / \mathrm{kg} /$ day & CREATINE $2 \mathrm{~g} / \mathrm{kg} /$ day \\
\hline Glucose (mg/dl) & $185.3 \pm 29.9$ & $197.3 \pm 33.5$ & $190.0 \pm 21.0$ & $181.7 \pm 26.7$ \\
\hline Creatinine (mg/dl) & $0.3 \pm 0.1$ & $0.2 \pm 0.2$ & $0.3 \pm 0.1$ & $0.3 \pm 0.1$ \\
\hline Total Cholesterol (mg/dl) & $59.5 \pm 18.0$ & $53.3 \pm 8.4$ & $54.2 \pm 15.8$ & $40.2 \pm 6.4$ \\
\hline Triglycerides (mg/dl) & $43.2 \pm 13.3$ & $41.5 \pm 11.0$ & $39.0 \pm 15.8$ & $35.0 \pm 7.0$ \\
\hline HDL-C (mg/dl) & $13.8 \pm 7.7$ & $10.8 \pm 4.1$ & $12.0 \pm 5.2$ & $8.3 \pm 4.3$ \\
\hline LDL-C (mg/dl) & $37.0 \pm 12.2$ & $34.2 \pm 11.0$ & $34.3 \pm 11.8$ & $24.8 \pm 9.2$ \\
\hline VLDL-C (mg/dl) & $8.6 \pm 2.7$ & $8.3 \pm 2.2$ & $7.8 \pm 3.2$ & $7.0 \pm 1.4$ \\
\hline AST (U/L) & $111.2 \pm 31.8$ & $153.5 \pm 84.2$ & $144.0 \pm 96.0$ & $177.3 \pm 91.3$ \\
\hline ALT (U/L) & $13.2 \pm 4.3$ & $19.2 \pm 6.9$ & $25.8 \pm 32.0$ & $22.2 \pm 11.6$ \\
\hline Alkaline Phosphatase (U/L) & $155.8 \pm 71.4$ & $219.3 \pm 68.0$ & $185.5 \pm 66.1$ & $165.5 \pm 32.5$ \\
\hline Total Protein $(\mathrm{g} / \mathrm{dl})$ & $6.0 \pm 0.7$ & $6.8 \pm 0.5$ & $6.4 \pm 0.5$ & $6.6 \pm 0.4$ \\
\hline $\operatorname{Albumin}(\mathrm{g} / \mathrm{dl})$ & $3.6 \pm 0.2$ & $3.8 \pm 0.2$ & $3.8 \pm 0.3$ & $3.8 \pm 0.3$ \\
\hline Urea (mg/dl) & $8.6 \pm 4.2$ & $7.1 \pm 4.9$ & $8.0 \pm 3.5$ & $9.5 \pm 3.1$ \\
\hline Creatinine Clearance $(\mathrm{ml} / \mathrm{min})$ & $0.4 \pm 0.4$ & $0.6 \pm 0.8$ & $0.5 \pm 0.5$ & $0.2 \pm 0.1$ \\
\hline
\end{tabular}


The analysis of fluid intake during the fourteen days of the experiment showed no significant daily changes $(p=0.1195)$ among the four groups (Figure 1).

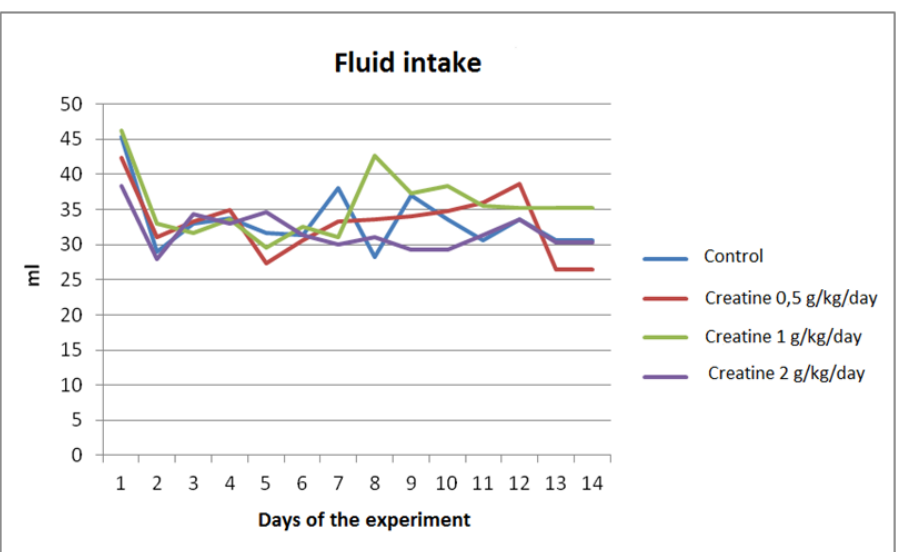

FIGURE 1 - Temporal change of fluid intake between the groups, during the fourteen days of the experiment.

Creatine supplementation at doses of $0.5 \mathrm{~g} / \mathrm{kg} /$ day; $1 \mathrm{~g} / \mathrm{kg} /$ day and $2 \mathrm{~g} / \mathrm{kg} /$ day did not produce significant daily changes $(\mathrm{p}=$ 0.6381) among the four groups (Figure 2).

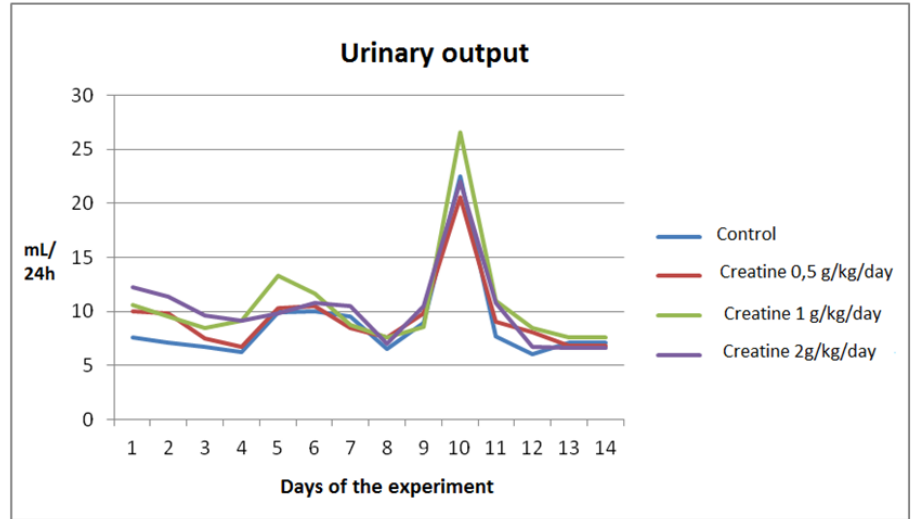

FIGURE 2 - Temporal change in urinary output among the groups, during the fourteen days of the experiment.

Likewise, food intake during the fourteen days of the experiment showed no significant daily changes $(p=0.7161)$ among the four groups (Figure 3).

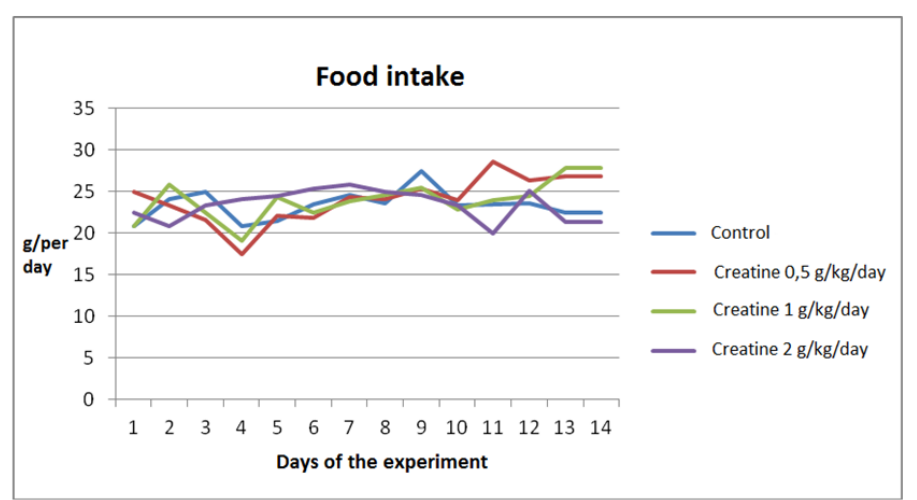

FIGURE 3 - Temporal change in food intake among the groups, during the fourteen days of the experiment.

\section{Discussion}

Creatine is a nitrogen amine referred to as methyl guanidine-acetic acid ${ }^{7}$. Its mechanism of action is based on the improvement of the muscle energy metabolism, in which the phosphorylated creatine has the ability to re-synthesize ATP ${ }^{19-21}$. Creatine supplementation also produces other beneficial effect, such as increased size of muscle fibers, as well as lean body mass. However, in light of these benefits it is necessary to analyze its toxic effect on kidney and liver metabolism.

This study demonstrated that supplementation with creatine at the given doses produced no significant changes in plasma levels of aspartate aminotransferase (AST), alanine aminotransferase (ALT), alkaline phosphatase, total protein, albumin, total cholesterol, HDL cholesterol, LDL cholesterol, VLDL cholesterol, triglycerides, glucose, creatinine, urea, and creatinine clearance, compared to the control group. Furthermore, it has shown that fluid intake, urinary output and daily food intake had no significant changes among the four groups, during the fourteen days of the experiment.

These results obtained are consistent with previous published studies. According to Vieira et al. $^{32}$ histological and biochemical analysis (levels of aspartate aminotransferase (AST), alanine aminotransferase (ALT), alkaline phosphatase (ALP), gamma-glutamyl transferase (GGT), total protein, albumin, total cholesterol, HDL cholesterol, LDL cholesterol, VLDL cholesterol, and triglycerides showed no significant liver change in the rats supplemented with creatine at a dose of $0.5 \mathrm{~g} / \mathrm{kg} /$ day, during the fourteen days of the experiment. However, such study examined the potential hepatotoxicity by using only a single dose of supplementation; additionally, only liver parameters were observed, and potential renal toxicity was not assessed, unlike the present study. 
Some studies have shown that elevations in plasma levels of liver enzymes, such as AST, ALT, GGT, and alkaline phosphatase are associated with increased metabolic rate in the liver, indicating liver toxicity, especially when exposed to drugs, viral or bacterial agents ${ }^{35}$.

Other studies have also evaluated liver and kidney toxicity in rats supplemented with creatine. However, the methodologies used in those studies are different from the ones in our study. For instance, Taes et al. ${ }^{31}$ have investigated the effect of creatine supplementation upon pre-existing renal disease. For such, they used rats with induced renal failure by surgical removal of $2 / 3$ of the kidney tissue. The animals were divided into four groups: false-operated control, false-operated creatine, 2/3 nephrectomized control and 2/3 nephrectomized creatine. After four weeks of supplementation, the data on cystatin c, inulin clearance of urea, creatinine and albumin and urinary protein excretion showed no effect of creatine supplementation, both in nephrectomized and in false-operated rats. The authors concluded that such supplementation does not damage renal function, even with pre-existing renal disease, which was also observed in the present study, where animals with intact renal function showed no changes after supplementation either.

On the other hand, Edmunds et al. ${ }^{36}$ have investigated the effect of creatine on renal function, by using Han:Sprague Dawley (SPRD-cy) rats model of polycystic kidney disease. These were divided into control and creatine groups $(2 \mathrm{~g} / \mathrm{kg}$ of diet for seven days, followed by $0.48 \mathrm{~g} / \mathrm{kg}$ of diet for 35 days). In this study, creatine was combined with glutamine (5:1). In this case, creatine caused the progression of polycystic kidney disease, since the rats had higher levels of kidney weight and kidney fluid content. In addition, animals experienced worsening of renal function, which was evidenced by decreased creatinine clearance, increased creatinine, and urea retention. However, in the study mentioned, animals had a previous history of renal pathology, differently from the present study, in which animals had intact kidney function. Furthermore, creatine was combined with glutamine, unlike the present study, which used only creatine as supplementation ${ }^{36}$.

Likewise, Tarnopolsky et al. ${ }^{33}$ evaluated the effects of creatine supplementation, at different doses, in the tissues of 21 rats, whether genetically modified or not, after 50, 56, 150, 159 and 365 days of creatine supplementation. The results showed that supplementation led to the appearance of a diffuse inflammatory infiltration of the liver, both in genetically and not genetically modified animals. In the study mentioned, no other changes were found in any of the 20 other tissues analyzed and it was concluded that creatine supplementation induces a setting of hepatotoxicity, regardless of the dose. However, the presence of isolated inflammatory foci in the liver could be considered as transient hepatic abnormalities, since the authors have showed no other change in morphology and liver function.

By virtue of the foregoing, gaps in literature are under analysis, taking into account potential nephrotoxicity and hepatotoxic of creatine supplementation in rats with intact renal and hepatic function, as in the present study. Therefore, dose- and time-dependent studies are needed to better understand the effects of creatine supplementation on liver and kidney metabolism. Similarly, studies on creatine supplementation effects on liver and kidney functions of physically active animals are also necessary, because despite several clinical applications of creatine, most of its use is associated with the practice of sports.

\section{Conclusion}

At the doses used, oral creatine supplementation did not result in renal and/or hepatic toxicity.

\section{References}

1. Mujika I, Padilla S. Creatine supplementation as an ergogenic aid for sports performance in highly trained athletes: a critical review. Int J Sports Nut. 1997;18:491-6. doi: 10.1055/s-2007-972670.

2. Franco FSC, Costa NMB, Oliveira TT, Gomes GJ, Silva KA, Natali AJ. Effects of creatine and caffeine supplementation on the bone breaking force in rats subjected to vertical jumping exercise. Rev Educ Fis. 2012;23(1):105-4. doi: 10.4025/reveducfis.v23i1.12285.

3. Williams MH. Nutritional ergogenics in athletics. J Sports Sci. 1995;13(Special Issue):S63-74. doi: 10.1080/02640419508732279.

4. Maughan RJ. Nutritional ergogenic aids and exercise performance. Nut Res Rev. 1999;12:255-80. doi: 10.1079/095442299108728956.

5. Rossi L, Tirapegui J. Aminoácidos: bases atuais para a suplementação na atividade física. Rev Bras Cienc Farm. 2000;36:37-51. PMID: 276135.

6. Gomes M, Tirapegui J. Relação de alguns suplementos nutricionais e desempenho físico. Arch Latinoam Nutr. 2001;51:317-29. PMID: 305239.

7. De Moraes SM, Brogio TA, Zanoni JN, Zapater MC, Peres SB, Hernandes L. Creatine supplementation in trained rats causes changes in myenteric neurons and intestinal wall morphometry. Biocell. 2013 Aug;37(2):37-43. PMID: 24392580.

8. Williams MH, Branch JD. Creatine supplementation and exercise performance: an update. J Am Coll Nutr. 1998;17:216-34. PMID: 9627907.

9. Greenhaf PL. Creatine and Its application as an ergogenic aid. Int J Sports Nut. 1995;5:S101-10. PMID: 7550252.

10. Brannon TA, Adams GR, Conniff CL, Baldwin KM. Effects of creatine loading and training on running performance and biochemical properties of rat skeletal muscle. Med Sci Sports Exerc. 1997;29:489-95. PMID: 9107631.

11. Pritchard NR, Kalra PA. Renal dysfunction accompanying oral creatine supplements. Lancet. 2008;351:1252-3. PMID: 9643752.

12. Feldman EB. Creatine: a dietary supplement and ergogenic aid. Nutr Rev. 1999;57:45-50. PMID: 10079702. 
13. Mendes RR, Tirapegui J. Creatina: o suplemento nutricional para a atividade física conceitos atuais. Arch Latinoam Nutr. 2002 Jun;52(2):117-27. PMID: 12184144.

14. Persky AM, Brazeau GA. Clinical pharmacology of the dietary supplement creatine monohydrate. Pharmacol Rev. 2001 Jun;53(2):161-76. PMID: 11356982.

15. Engelhardt M, Neumann G, Berbalk A, Reuter I. Creatine supplementation in endurance sports. Med Sci Sports Exerc. 1998;30:1123-9. PMID: 9662683.

16. Greenhaf PL, Bodin K, Soderlund K, Hultman. Effect of oral creatine supplementation on skeletal muscle phosphocreatine resynthesis. Am J Physiol. 1994;266:E725-30. PMID: 8203511.

17. Calfee R, Fadale P. Popular ergogenic drugs and supplements in young athletes. Pediatrics. 2006;117:e577-89. doi: 10.1542/ peds.2005-1429.

18. Maughan RJ, King DS, Lea T. Dietary supplements. J Sports Sci. 2004;22:95-113. doi: 10.1080/0264041031000140581.

19. Alves C, Lima RVB. Uso de suplementos alimentares por adolescentes. J Pediatr. 2009;85(4):287-94. doi: org/10.1590/ S0021-75572009000400004.

20. Ahrendt DM. Ergogenic aids: counseling the athlete. Am Fam Physician. 2001;63:913-22. PMID: 11261867.

21. Preen D, Dawson B, Goodman C, Lawrence S, Beilby J, Ching S. Effect of creatine loading on long-term sprint exercise performance and metabolism. Med Sci Sports Exerc. 2001;33:814-21. PMID: 11323554.

22. Balsom PD, Söderlund K, Ekblom B. Creatine in humans with special reference to creatine supplementation. Sports Med. 1994;18:268-80. PMID: 7817065.

23. Gualano B, Acquesta FM, Ugrinowitsch C, Tricoli V, Serrão JC, Lancha Junior AH. Efeitos da suplementação de creatina sobre força e hipertrofia muscular: atualizações. Rev Bras Med Esporte. 2010 May;16(3):219-23. doi: org/10.1590/S1517-86922010000300013.

24. Andreassen OA, Jenkins BG, Dedeoglu A, Ferrante KL, Bogdanov MB, Kaddurah-Daouk R, Beal MF. Increases in cortical glutamate concentrations in transgenic amyotrophic lateral sclerosis mice are attenuated by creatine supplementation. J Neurochem. 2001 Apr;77(2):383-90. doi: 10.1046/j.1471-4159.2001.00188.x.

25. Prass K, Royl G, Lindauer U, Freyer D, Megow D, Dirnaql U, Stöckler-Ipsiroglu G, Wallimann T, Priller J. Improved reperfusion and neuroprotection by creatine in a mouse model of stroke. J Cereb Blood Flow Metab. 2007 Mar;27(3):452-9. PMID: 16773141.

26. Halliwell B. Oxidative stress and neurodegeneration: where are we now? J Neurochem. 2006;97(6):1634-58. doi: 10.1111/j.14714159.2006.03907.x.

27. Halliwell B. Reactive species and antioxidants. Redox biology is a fundamental theme of aerobic life. Plant Physiol. 2006;141(2):31222. doi: org/10.1104/pp.106.077073.

28. McConell GK, Shinewell J, Stephens TJ, Stathis CG, Canny BJ, Snow RJ. Creatine supplementation reduces muscle inosine monophosphate during endurance exercise in humans. Med Sci Sports Exerc. 2005;37(12):2054-61. PMID: 16331129.

29. Souza Junior TP, Pereira B. Creatina: auxílio ergogênico com potencial antioxidante? Rev Nutr. 2008;21(3):349-53. doi: org/10.1590/S1415-52732008000300010.

30. Gualano B, Ugrinowitsch C, Seguro AC, Lancha Junior AHL. A suplementação de creatina prejudica a função renal? Rev Bras Med Esporte. 2008;14(1):68-73. doi: org/10.1590/S151786922008000100013
31. Taes YE, Delanghe JR, Wuyts B, van de Voorde J, Lameire NH. Creatine supplementation does not affect kidney function in an animal model with pre-existing renal failure. Nephrol Dial Transplant. 2003;18:258-64. doi: 10.1093/ndt/18.2.258.

32. Vieira RP, França RF, Carvalho CRF, Dolhnikoff M, Ribeiro W, Martins RABL. Efeitos da suplementação oral com creatina sobre o metabolismo e a morfologia hepática em ratos. Rev Bras Med Esporte. 2008;14(1):38-41. doi: org/10.1590/S151786922008000100007.

33. Tarnopolsky MA, Bourgeois JM, Snow R, Keys S, Roy BD, Kwiecien JM, Kwiecien JM, Turnbull J. Histological assessment of intermediate- and long-term creatine monohydrate supplementation in mice and rats. Am J Physiol Regul Integr Comp Physiol. 2003 Oct;285(4):R762-9. doi: 10.1152/ajpregu.00270.2003.

34. Ferreira LG, De Toledo Bergamaschi C, Lazaretti-Castro M, Heilberg IP. Effects of creatine supplementation on body composition and renal function in rats. Med Sci Sports Exerc. 2005;37:1525-9. PMID: 16177604.

35. Takahashi H, Fujimoto J, Hanada S, Isselbacher KJ. Acute hepatitis in rats expressing human hepatitis B virus transgenes. Proc Natl Acad Sci USA. 1995 Feb 28;92(5):1470-4. doi: 10.1073/pnas.92.5.1470.

36. Edmunds JW, Jayapalan S, DiMarco NM, Saboorian MH and Aukema HM. Creatine supplementation increases renal disease progression in Han: SPRD-cy rats. Am J Kidney Dis. 2001;37:73-8. doi: org/10.1053/ajkd.2001.20590.

\section{Acknowledgements}

To Flávia de Souza and Beatriz Minamisako for reviewing the English version.

\section{Correspondence:}

Nilo César do Vale Baracho

Faculdade de Medicina de Itajubá

Avenida Renó Junior, 368

37502-138 Itajubá - MG Brasil

Tel.: (55 35)3629-8700

nilocvbaracho@yahoo.com.br

Received: Jan 18, 2015

Review: Mar 19, 2015

Accepted: Apr 20, 2015

Conflict of interest: none

Financial sources: Development Program of Undergraduate Research, School of Medicine Itajuba (PDIC-FMIt) and Minas Gerais State Research Support Foundation (FAPEMIG)

${ }^{1}$ Research performed at Biochemistry Laboratory, Medical School of Itajuba (FMIt), Brazil. 